\title{
Labeling and Imaging of Stem Cells - Promises and Concerns
}

\author{
Richard Schäfer \\ Institute of Clinical and Experimental Transfusion Medicine, University Hospital Tuebingen, Germany
}

\author{
Key Words \\ Labeling · Imaging $\cdot$ Stem cells $\cdot$ SPIO $\cdot$ MRI
}

\section{Summary}

For experimental and clinical applications of stem cells cell labeling and tracking is interesting to evaluate cell distribution and homing. Tracking of cells after transplantation can be performed for monitoring the delivery and faith of the graft. Furthermore, imaging techniques are part of the evaluation of the functional effects of cellular therapy in the organism of the host. Therefore, systematic investigations on the development and clinical evaluation of imaging techniques and their possible biological impact on stem cells is an emerging topic of today's applied stem cell research. This article refers to different labeling techniques of stem cells highlighting their promises for clinical use and discussing their possible risks.

\section{Introduction}

Recent advances in molecular biology, human genetics, immunotherapies as well as stem cell therapies resulted in a better understanding of the underlying pathologies in several diseases. Early detection as well as specification of pathological conditions is crucial with respect to initiating new and sometimes very expensive therapies. Hand in hand with new thera-

\author{
Schlüsselwörter \\ Markierung · Bildgebende Verfahren - Stammzellen · \\ SPIO $\cdot$ MRT
}

\section{Zusammenfassung}

Für experimentelle und klinische Anwendungen ist die Markierung von Stammzellen sowie deren Nachverfolgung nach Transplantation vor allem bezüglich des "Homing" von Interesse. Die Nachverfolgung von Zellen nach deren Transplantation kann zur unmittelbaren Überprüfung der Zellapplikation sowie zur Evaluation des weiteren Schicksals des Transplantats erfolgen. Weiterhin sind bildgebende Verfahren Teil des Evaluationsprozesses von funktionellen Effekten der Zelltherapie im Empfänger. Deshalb sind systematische Untersuchungen von Neuentwicklungen von bildgebenden Verfahren und deren sorgfältige klinische Evaluation, auch im Hinblick auf deren mögliche Auswirkungen auf Stammzellen, ein wichtiger Aspekt in der aktuellen Stammzellforschung. Dieser Artikel beleuchtet verschiedene Markierungstechniken von Stammzellen und diskutiert deren Aussichten für die klinische Anwendung sowie deren mögliche Risiken.

peutic strategies better imaging modalities have to be developed in order to optimize therapy monitoring. Considering the emerging future potential of stem cell therapies, new, non-invasive and sensitive imaging modalities have been developed $[1,2]$. For experimental and clinical applications of stem cells cell labeling and tracking is interesting to evaluate cell distribution and homing. Tracking of cells after transplantation may be performed for monitoring the delivery and fate of the graft.

\section{KARGER}

Fax +497614520714

Information@Karger.de

www.karger.com (c) 2010 S. Karger GmbH, Freiburg

Accessible online at:

www.karger.com/tmh
Dr. Richard Schäfer

Harvard Stem Cell Institute

Department of Stem Cell and Regenerative Biology, Harvard University

7 Divinity Avenue, Boston MA 02138, USA

Tel. +16176433410

richard_schaefer@mgh.harvard.edu 
Furthermore, imaging techniques are part of the evaluation of the functional effects of cellular therapy in the organism of the host. Non-invasive visualization of the biological properties of the donor cells after transplantation, e.g. with respect to survival, proliferation and differentiation, as well as visualization of the interactions of the graft with the host tissue are a goal of modern molecular medicine [3, 4]. Meanwhile, the first patients have been treated with labeled cells in clinical trials [5]. However, the book of knowledge about these methods is not yet finished. Therefore, systematic investigations on the development and clinical evaluation of imaging techniques and their possible biological impact on stem cells are emerging topics of today's applied stem cell research.

\section{Principles and Techniques of Cell Imaging}

Cell imaging strategies include ultrasound (US) [6], positron emission tomography (PET) imaging [7], single photon emission computer tomography (SPECT) [8], optical imaging (OI) [9], and magnetic resonance imaging (MRI) [10-12], all of them with strengths and weaknesses.

US is a cheap method which can be performed without sumptuous preparations; however, the spatial resolution is limited and the detection of the specific signal could be hindered, e.g. by gas-containing compartments like the gastrointestinal system.

Although providing excellent sensitivity, limitations of PET imaging are its limited spatial resolution [13] and the relatively short half-life time of several tracers (e.g. F-18 $\mathrm{T}_{1 / 2}=$ $110 \mathrm{~min}$ ); thus PET imaging would be possible only within a short period after cell application.

Another very sensitive modality is OI, which can be helpful especially in small animal models [14]. However, OI is of limited value when imaging humans due to its poor tissue penetration (only a few centimeters when using fluorochromes at a wavelength of $700-800 \mathrm{~nm}$ ). An additional problem is the quantification of the signal.

MRI at higher field strength ( $\geq 1.5$ Tesla) could be a good compromise when using special amplification methods as well as dedicated sequences and coils. Compared to PET and OI, the sensitivity of MRI is lower by the factor $10^{2}-10^{5}$, depending on the structures examined. On the other hand, MRI offers a superb spatial resolution $(300 \mu \mathrm{m}$ can be easily achieved compared to 5-10 mm using PET). Other advantages of MRI are the lack of radiation exposure, and object/patient size ('being to large') is not a limiting issue. Additionally, repetitive examinations over a longer time period (up to 6 weeks) have already been performed successfully [15]. Due to its high resolution and excellent tissue contrast, MRI has been most widely applied to track stem cells after transplantation [16].

\section{Principles and Techniques of Cell Labeling}

To detect cells by contrast-enhanced US they can be labeled with microbubbles targeting e.g. specific receptors expressed on the surface of the target cells [6].

The principle of PET is the detection of radioactive tracers. The cells can be directly labeled before transplantation e.g. by incubation with indium-111-oxine $\left({ }^{111} \mathrm{In}\right)[17,18]$ or fluorine18-fluordeoxyglucose (FDG) [19]. Another interesting approach of cell labeling for PET or SPECT imaging is the enhanced uptake of systematically applied tracers into the donor cells after transplantation. Before transplantation, the cells are transfected with a reporter gene like the sodium iodide symporter which promotes the in vivo cellular uptake of technetium $99 \mathrm{~m}\left({ }^{99 \mathrm{~m}} \mathrm{Tc}\right)$ or iodine $124\left({ }^{124} \mathrm{I}\right)$ [20].

The generation of images by MRI is based on the variable arrangement of protons induced by magnetization and their re-arrangement (relaxation) after change of the magnetic field induced by the MRI scanner. Two relaxation time constants T1 and T2 are utilized to generate tissue contrast [21]. Principally, there are two major ways to label cells for MRI: using paramagnetic substances or superparamagnetic substances. Paramagnetic substances such as gadolinium (Gd) reduce the $\mathrm{T} 1$ relaxation time producing a hyperintensive (positive $=$ white $)$ contrast [21-25]. However, the current protocols basing on paramagnetic labeling reagents seem to be inferior to superparamagnetic agents in terms of cytotoxicity and ability of generating images of strong contrast [21]. Superparamagnetic agents are mainly basing on iron $(\mathrm{Fe})$. They reduce the $\mathrm{T} 2$ relaxation time leading to a strong hypointensive (negative $=$ black) contrast [21]. Iron labeling is usually performed using superparamagnetic small particles of iron oxide (SPIO) or ultrasmall particles of iron oxide (USPIO) [26-28]. They differ mainly in their particle size $(20-120 \mathrm{~nm})$ and their coating ((carboxy)dextran). SPIO like Endorem ${ }^{\circledR}$ (Guerbet, Paris, France) or Resovist ${ }^{\circledR}$ (Schering AG, Berlin, Germany) are already approved for clinical purposes (liver imaging). Labeling of various cell entities like immune cells and hematopoietic and non-hematopoietic stem cells with superparamagnetic agents such as particles of iron oxide has been established previously [29-31]. So far, many Fe labeling protocols are based on passive $\mathrm{Fe}$ incorporation by endocytosis whilst in vitro incubation of the cells with the labeling agent [32]. However, the total iron load (TIL) of each cell declines by each cell division. As the TIL correlates with the imaging quality [33], transfection agents (TA) are applied being helpful with respect of transporting Fe into the target cell. Currently used TA are lipofectamine [34], poly-L-lysine [35], protamine sulphate [36] and polethylenimine (PEI) [37]. The positively charged TA, coating the negatively charged SPIO, leads to an enhanced SPIO-cell binding via electrostatic interactions and finally to an enhanced uptake into the cell [29]. Interestingly, although significantly enhancing the TIL, complexes of TA and SPIO may remain for a certain time on the cellular sur- 
face before being taken up [37]. If this phenomenon may have an impact e.g. on extracellularly expressed receptors and the interaction with their ligands remain to be elucidated. Moreover, with respect to the principles of good manufacturing practice (GMP), a prolonged in vitro incubation time with all its risks of cell culture may not be desirable. Therefore, advanced techniques have been developed in order to deliver the labeling agent as quick as possible into the cell. Exposing the cells to an electrical pulse $(130 \mathrm{~V})$ provokes a temporal increase of the permeability of the cell membrane, leading to an enhanced uptake of the labeling agent into the cell. This method called magnetoelectroporation is effective in terms of labeling of many cells in a very short time [38, 39]. Magnetosonoporation can also increase the permeability of the cell membrane in order to enhance the uptake of the labeling agent. Exposure to low frequency US (1-3 MHz) can create temporary pores into the cell membrane of up to $100 \mathrm{~nm}$ by the acoustic cavitation effect [40, 41]. Liu et al. [42] effectively labeled human mesenchymal stem cells (MSCs) with SPIO by microbubble enhanced US exposure, referring to previous reports that US exposure in the presence of microbubbles can increase the transfection efficiency $[43,44]$. An alternative approach combining stem cell labeling for MRI with specific positive selection techniques is the use of magnetic beads linked to specific antibodies such as anti-CD34 [45] or specific aptamers [46].

Referring to the sensitivity, using clinical MRI scanners 5,000 SPIO+TA labeled stem cells could be detected in vitro [33], and the sensitivity of Fe labeling of cells in vivo allowed even single cell detection by MRI in small animal models [47, 48].

Even if 'simple' Fe labeling appears attractive and potent, one major limitation is that the detected signal refers only to the applied Fe particles and gives no information about the viability and the biological status (differentiation, metabolic or mitotic activity) of the cell labeled prior to the transplantation. Moreover, the signal may be generated from $\mathrm{Fe}$ particles which were detached from the labeled donor cells and/or ingested into host cells. In order to overcome these problems of direct cell labeling, reporter gene methods were also developed for cell imaging by MRI.

Introducing a metalloprotein from the ferritin family as a reporter gene, the transduced cells sequestered endogenous (superparamagnetic) Fe from the organism [49]. No exogenous metal complexed contrast agent was required, thereby simplifying intracellular delivery. Following focal inoculation of the vector into the mouse brain, the reporter activity was monitored using in vivo MRI.

Gilad et al. [50] designed a non-metallic, biodegradable, lysine rich protein reporter, expressing an artificial protein with frequency selective contrast. This endogenous contrast produced only by transfected viable cells is based on transfer of radiofrequency labeling from the reporter's amide protons to water protons.
It is assumed that more reporter gene based technologies for 'smart imaging' of distinct properties of transplanted stem cells will be developed in the near future.

\section{Concerns about Cell Labeling}

Every technique has its limitations and possible undesired effects, and this is also the case for cell labeling. Little is known about the use of ionizing radiation by PET tracers with respect to possible effects on the DNA. The high voltage treatment of the cells using magnetoelectroporation may negatively affect cell types with functionally important electrophysiological properties like neural stem cells (NSCs), neuronal cells or cardiomyocytes, or generally affect the viability of sensitive cells. Reporter gene techniques appear to have a bright and promising future. However, what do we know today about long-term effects of genetic engineering, even if transgene silencing is a major goal?

Referring to the 'simple' Fe labeling techniques using even clinically established SPIO, emerging reports highlight undesired effects of cell labeling. Despite the initial assumption that internalized SPIO may be metabolically 'inert', there is evidence that the Fe particles interact with the cell's iron metabolism [33, 51]. Currently it is unclear which long-term effects this interaction may have. Referring to functional effects of labeling on stem cells, SPIO labeling with TA of rat MSCs led to an increase in disease severity in a rat model of multiple sclerosis [52]. Moreover, labeling of human MSCs with SPIO in combination with TA led to a decrease of migration capacity in vitro, and labeling of human MSCs with SPIO with and without TA led to a significant decrease of ability of colony formation [37]. Kostura et al. [53] reported on the inhibition of chondrogenic differentiation capacity of human MSCs by SPIO labeling. Another study reported on the shift of (U) SPIO labeled macrophages toward an anti-inflammatory, less responsive phenotype and the influence of macrophage labeling on the $\mathrm{T}$ cell-macrophage interaction [54]. But also TA like poly-L-lysine or PEI may cause serious side effects such as fibrosis or cytotoxicity $[55,56]$.

\section{Clinical Studies}

In 2003 de Vries et al. [57] tracked successfully the migration of dendritic cells (DCs) to lymph nodes in melanoma patients by in vivo imaging of ${ }^{111} \mathrm{In}$ labeled DCs by scintigraphy. To date there are reports on four completed clinical studies on MRI imaging of labeled cells in humans.

In the first MRI study again melanoma patients were enrolled: They received autologous DCs labeled with SPIO without TA or ${ }^{111}$ In labeled DCs injected into the lymph nodes. In contrast to scintigraphic imaging, MRI allowed assessment of the accuracy of DC delivery and of inter- and intra-nodal cell 
migration patterns. In this study, the detection limit by MRI was calculated of about 15,000 SPIO labeled DCs. Importantly, a clinically highly valuable result was that the in vivo MRI revealed a high misinjection rate of about $50 \%-$ a finding that would not be generated without the use of MRI [58].

A case report of a patient with traumatic brain injury receiving autologous NSCs marks the second clinical application and imaging of Fe labeled cells: The NSCs were labeled with SPIO in combination with TA and injected stereotactically into the brain. MRI showed a migration of the NSCs toward the site of the injury [59]. Another group performed successfully MRI imaging of bone marrow derived CD34+ cells in patients with chronic spinal cord injury. The cells were labeled with large magnetic 'macrobeads' (mean diameter about $4 \mu \mathrm{m}$ ) linked to anti-CD34 antibodies and were applied into the spinal cord [60]. Finally, a Swiss study reported on a clinical investigation of diabetic patients receiving intraportally SPIO labeled islets [61]. The signal could be detected by MRI in a long-term follow-up for 6 months, and no functional affection of the cellular graft with respect to insulin production could be observed.

\section{Conclusion}

Labeling and imaging of (stem) cells is feasible, and imaging by MRI seems to be the most promising approach for possible clinical applications. Certainly, new therapeutic strategies, e.g. in the emerging field of regenerative medicine, imply a need of knowledge about the homing and survival of the cellular graft. Here, basic research was brilliantly performed in animal models $[8,10,15,29,62]$. Moreover, there is a realistic chance that we could gain new insights of stem cell function and diseases using advanced cell labeling techniques. However, referring to the concerns, the basic principle for all medical treatments and diagnostics may always be 'nihil nocere'. As hematopoietic stem cell transplantation has been performed successfully for decades, no urgent need was and maybe is for individual imaging of the cellular graft in each patient. Therefore, the goals and risks of cell labeling and imaging may be considered when proceeding on introducing advanced labeling techniques into the clinic.

\section{Disclosure}

The author declared no conflict of interest.

\section{References}

1 Unger EC: How can superparamagnetic iron oxides be used to monitor disease and treatment? Radiology 2003;229:615-616.

2 Dick AJ, Guttman MA, Raman VK, Peters DC, Pessanha BS, Hill JM, et al: Magnetic resonance fluoroscopy allows targeted delivery of mesenchymal stem cells to infarct borders in swine. Circulation 2003;108:2899-2904.

3 Massoud TF, Gambhir SS: Molecular imaging in living subjects: seeing fundamental biological processes in a new light. Genes Dev 2003;17:545-580.

$\checkmark 4$ Massoud TF, Gambhir SS: Integrating noninvasive molecular imaging into molecular medicine: an evolving paradigm. Trends Mol Med 2007;13: 183-191.

5 Bulte JW: In vivo MRI cell tracking: clinical studies. AJR Am J Roentgenol 2009;193:314-325.

6 Kuliszewski MA, Fujii H, Liao C, Smith AH, Xie A, Lindner JR, et al: Molecular imaging of endothelial progenitor cell engraftment using contrastenhanced ultrasound and targeted microbubbles. Cardiovasc Res 2009;83:653-662.

7 Huang J, Lee CC, Sutcliffe JL, Cherry SR, Tarantal $\mathrm{AF}$ : radiolabeling rhesus monkey CD34(+) hematopoietic and mesenchymal stem cells with $(64) \mathrm{Cu}$ pyruvaldehyde-bis(N4-methylthiosemicarbazone) for microPET imaging. Mol Imaging 2008;7:1-11.

8 Kraitchman DL, Tatsumi M, Gilson WD, Ishimori T, Kedziorek D, Walczak P, et al: Dynamic imaging of allogeneic mesenchymal stem cells trafficking to myocardial infarction. Circulation 2005;112: 1451-1461.
9 Boddington SE, Henning TD, Jha P, Schlieve CR, Mandrussow L, Denardo D, et al: Labeling human embryonic stem cell derived cardiomyocytes with indocyanine green for noninvasive tracking with optical imaging: an FDA compatible alternative to firefly luciferase. Cell Transplant 2009; doi: 10.3727/096368909X478579

10 Kraitchman DL, Heldman AW, Atalar E, Amado LC, Martin BJ, Pittenger MF, et al: In vivo magnetic resonance imaging of mesenchymal stem cells in myocardial infarction. Circulation 2003:107:2290-2293.

11 Hauger O, Frost EE, van HR, Deminiere C, Xue $\mathrm{R}$, Delmas Y, et al: MR evaluation of the glomerular homing of magnetically labeled mesenchymal stem cells in a rat model of nephropathy. Radiology 2006;238:200-210.

12 Bos C, Delmas Y, Desmouliere A, Solanilla A, Hauger $\mathrm{O}$, Grosset $\mathrm{C}$, et al: In vivo MR imaging of intravascularly injected magnetically labeled mesenchymal stem cells in rat kidney and liver. Radiology 2004;233:781-789.

13 Luker GD, Piwnica-Worms D: Molecular imaging in vivo with PET and SPECT. Acad Radiol 2001; 8:4-14.

14 Mahmood U, Weissleder R: Near-infrared optical imaging of proteases in cancer. Mol Cancer Ther 2003;2:489-496.

15 Bulte JW, Douglas T, Witwer B, Zhang SC, Strable E, Lewis BK, et al: Magnetodendrimers allow endosomal magnetic labeling and in vivo tracking of stem cells. Nat Biotechnol 2001;19:1141-1147.

16 Kraitchman DL, Bulte JW: Imaging of stem cells using MRI. Basic Res Cardiol 2008;103:105-113.
17 Lavender JP, Goldman JM, Arnot RN, Thakur ML: Kinetics of indium-III labelled lymphocytes in normal subjects and patients with Hodgkin's disease. Br Med J 1977;ii(6090):797-799.

18 Thakur ML, Segal AW, Louis L, Welch MJ, Hopkins J, Peters TJ: Indium-111-labeled cellular blood components: mechanism of labeling and intracellular location in human neutrophils. J Nucl Med 1977; 18:1022-1026.

19 Doyle B, Kemp BJ, Chareonthaitawee P, Reed C, Schmeckpeper J, Sorajja P, et al: Dynamic tracking during intracoronary injection of 18 F-FDG-labeled progenitor cell therapy for acute myocardial infarction. J Nucl Med 2007;48:1708-1714.

20 Terrovitis J, Kwok KF, Lautamaki R, Engles JM, Barth AS, Kizana E, et al: Ectopic expression of the sodium-iodide symporter enables imaging of transplanted cardiac stem cells in vivo by singlephoton emission computed tomography or positron emission tomography. J Am Coll Cardiol 2008; 52:1652-1660.

21 Long CM, Bulte JW: In vivo tracking of cellular therapeutics using magnetic resonance imaging. Expert Opin Biol Ther 2009;9:293-306.

22 Huber MM, Staubli AB, Kustedjo K, Gray MH, Shih J, Fraser SE, et al: Fluorescently detectable magnetic resonance imaging agents. Bioconjug Chem 1998;9:242-249.

23 Flacke S, Fischer S, Scott MJ, Fuhrhop RJ, Allen JS, McLean M, et al: Novel MRI contrast agent for molecular imaging of fibrin: implications for detecting vulnerable plaques. Circulation 2001; 104:1280-1285. 
24 Modo M, Cash D, Mellodew K, Williams SC, Fraser SE, Meade TJ, et al: Tracking transplanted stem cell migration using bifunctional, contrast agentenhanced, magnetic resonance imaging. Neuroimage 2002;17:803-811.

25 Daldrup-Link HE, Rudelius M, Metz S, Piontek G, Pichler B, Settles M, et al: Cell tracking with gadophrin-2: a bifunctional contrast agent for MR imaging, optical imaging, and fluorescence microscopy. Eur J Nucl Med Mol Imaging 2004;31:1312-1321.

-26 Reimer P, Weissleder R, Lee AS, Wittenberg J, Brady TJ: Receptor imaging: application to MR imaging of liver cancer. Radiology 1990;177:729-734.

27 Yeh TC, Zhang W, Ildstad ST, Ho C: In vivo dynamic MRI tracking of rat T-cells labeled with superparamagnetic iron-oxide particles. Magn Reson Med 1995;33:200-208.

28 Schoepf U, Marecos EM, Melder RJ, Jain RK, Weissleder R: Intracellular magnetic labeling of lymphocytes for in vivo trafficking studies. Biotechniques 1998;24:642-651.

29 Qiu B, Yang X: Molecular MRI of hematopoietic stem-progenitor cells: in vivo monitoring of gene therapy and atherosclerosis. Nat Clin Pract Cardiovasc Med 2008;5:396-404.

\30 Schäfer R, Dominici M, Muller I, Horwitz E, Asahara T, Bulte J, et al: Basic research and clinical applications of non-hematopoietic stem cells, 4-5 April 2008, Tubingen, Germany. Cytotherapy 2009; 11(2):245-255.

-31 Kraitchman DL, Bulte JW: In vivo imaging of stem cells and beta cells using direct cell labeling and reporter gene methods. Arterioscler Thromb Vasc Biol 2009;29:1025-1030.

-32 Daldrup-Link HE, Rudelius M, Piontek G, Metz S, Brauer R, Debus G, et al: Migration of iron oxidelabeled human hematopoietic progenitor cells in a mouse model: in vivo monitoring with 1.5-T MR imaging equipment. Radiology 2005;234:197-205.

-33 Schäfer R, Kehlbach R, Wiskirchen J, Bantleon R, Pintaske J, Brehm BR, et al: Transferrin receptor upregulation: in vitro labeling of rat mesenchymal stem cells with superparamagnetic iron oxide. Radiology 2007;244:514-523.

-34 Hoehn M, Kustermann E, Blunk J, Wiedermann D, Trapp T, Wecker S, et al: Monitoring of implanted stem cell migration in vivo: a highly resolved in vivo magnetic resonance imaging investigation of experimental stroke in rat. Proc Natl Acad Sci U S A 2002;99:16267-16272.

35 Frank JA, Miller BR, Arbab AS, Zywicke HA, Jordan EK, Lewis BK, et al: Clinically applicable labeling of mammalian and stem cells by combining superparamagnetic iron oxides and transfection agents. Radiology 2003;228:480-487.

-36 Arbab AS, Yocum GT, Kalish H, Jordan EK, Anderson SA, Khakoo AY, et al: Efficient magnetic cell labeling with protamine sulfate complexed to ferumoxides for cellular MRI. Blood 2004;104:1217-1223.
37 Schäfer R, Kehlbach R, Müller M, Bantleon R, Kluba T, Ayturan M, et al: Labeling of human mesenchymal stromal cells with superparamagnetic iron oxide leads to a decrease in migration capacity and colony formation ability. Cytotherapy 2009;11:68-78.

38 Walczak P, Kedziorek DA, Gilad AA, Lin S, Bulte JW: Instant MR labeling of stem cells using magnetoelectroporation. Magn Reson Med 2005;54:769-774.

39 Walczak P, Ruiz-Cabello J, Kedziorek DA, Gilad AA, Lin S, Barnett B, et al: Magnetoelectroporation: improved labeling of neural stem cells and leukocytes for cellular magnetic resonance imaging using a single FDA-approved agent. Nanomedicine 2006;2:89-94.

$40 \mathrm{Wu}$ J, Nyborg WL. Ultrasound, cavitation bubbles and their interaction with cells. Adv Drug Deliv Rev 2008;60:1103-1116.

41 Miller DL, Pislaru SV, Greenleaf JE: Sonoporation: mechanical DNA delivery by ultrasonic cavitation. Somat Cell Mol Genet 2002;27:115-134.

42 Liu ZY, Wang Y, Liang CH, Li XH, Wang GY, Liu $\mathrm{HJ}$, et al: In vitro labeling of mesenchymal stem cells with superparamagnetic iron oxide by means of microbubble-enhanced US exposure: initial experience. Radiology 2009;253:153-159.

43 Sonoda S, Tachibana K, Uchino E, Okubo A, Yamamoto M, Sakoda K, et al: Gene transfer to corneal epithelium and keratocytes mediated by ultrasound with microbubbles. Invest Ophthalmol Vis Sci 2006; 47:558-564.

44 Hernot S, Klibanov AL: Microbubbles in ultrasound-triggered drug and gene delivery. Adv Drug Deliv Rev 2008;60:1153-1166.

45 Jendelova P, Herynek V, Urdzikova L, Glogarova K, Rahmatova S, Fales I, et al: Magnetic resonance tracking of human CD34+ progenitor cells separated by means of immunomagnetic selection and transplanted into injured rat brain. Cell Transplant 2005;14:173-182.

46 Schäfer R, Wiskirchen J, Guo K, Neumann B, Kehlbach R, Pintaske J, et al: Aptamer-based isolation and subsequent imaging of mesenchymal stem cells in ischemic myocard by magnetic resonance imaging. Rofo 2007;179:1009-1015.

47 Shapiro EM, Sharer K, Skrtic S, Koretsky AP: In vivo detection of single cells by MRI. Magn Reson Med 2006;55:242-249.

48 Heyn C, Ronald JA, Mackenzie LT, MacDonald IC, Chambers AF, Rutt BK, et al: In vivo magnetic resonance imaging of single cells in mouse brain with optical validation. Magn Reson Med 2006;55:23-29.

49 Genove G, DeMarco U, Xu H, Goins WF, Ahrens ET: A new transgene reporter for in vivo magnetic resonance imaging. Nat Med 2005;11:450-454.

50 Gilad AA, McMahon MT, Walczak P, Winnard PT Jr, Raman V, van Laarhoven HW, et al: Artificial reporter gene providing MRI contrast based on proton exchange. Nat Biotechnol 2007;25:217-219.
1 Pawelczyk E, Arbab AS, Pandit S, Hu E, Frank JA: Expression of transferrin receptor and ferritin following ferumoxides-protamine sulfate labeling of cells: implications for cellular magnetic resonance imaging. NMR Biomed 2006;19:581-592.

52 Schäfer R, Ayturan M, Bantleon R, Kehlbach R, Siegel G, Pintaske J, et al: The use of clinically approved small particles of iron oxide (SPIO) for labeling of mesenchymal stem cells aggravates clinical symptoms in experimental autoimmune encephalomyelitis and influences their in vivo distribution. Cell Transplant 2008;17:923-941.

53 Kostura L, Kraitchman DL, Mackay AM, Pittenger MF, Bulte JW: Feridex labeling of mesenchymal stem cells inhibits chondrogenesis but not adipogenesis or osteogenesis. NMR Biomed 2004; 17:513-517.

54 Siglienti I, Bendszus M, Kleinschnitz C, Stoll G: Cytokine profile of iron-laden macrophages: implications for cellular magnetic resonance imaging. J Neuroimmunol 2006;173:166-173.

55 Strand BL, Ryan TL, In’t VP, Kulseng B, Rokstad AM, Skjak-Brek G, et al: Poly-L-lysine induces fibrosis on alginate microcapsules via the induction of cytokines. Cell Transplant 2001;10:263-275.

56 Choi YR, Chae SY, Ahn CH, Lee M, Oh S, Byun $\mathrm{Y}$, et al: Development of polymeric gene delivery carriers: PEGylated copolymers of L-lysine and Lphenylalanine. J Drug Target 2007;15:391-398.

57 de Vries IJ, Krooshoop DJ, Scharenborg NM, Lesterhuis WJ, Diepstra JH, Van Muijen GN, et al: Effective migration of antigen-pulsed dendritic cells to lymph nodes in melanoma patients is determined by their maturation state. Cancer Res 2003;63:12-17.

58 de Vries IJ, Lesterhuis WJ, Barentsz JO, Verdijk P, van Krieken JH, Boerman OC, et al: Magnetic resonance tracking of dendritic cells in melanoma patients for monitoring of cellular therapy. Nat Biotechnol 2005;23:1407-1413.

59 Zhu J, Zhou L, XingWu F: Tracking neural stem cells in patients with brain trauma. N Engl J Med 2006;355:2376-2378.

60 Callera F, de Melo CM: Magnetic resonance tracking of magnetically labeled autologous bone marrow CD34+ cells transplanted into the spinal cord via lumbar puncture technique in patients with chronic spinal cord injury: CD34+ cells' migration into the injured site. Stem Cells Dev 2007;16:461-466.

61 Toso C, Vallee JP, Morel P, Ris F, Muylder-Mischler $\mathrm{S}$, Lepetit-Coiffe M, et al: Clinical magnetic resonance imaging of pancreatic islet grafts after iron nanoparticle labeling. Am J Transplant 2008;8:701-706

62 Hill JM, Dick AJ, Raman VK, Thompson RB, Yu ZX, Hinds KA, et al: Serial cardiac magnetic resonance imaging of injected mesenchymal stem cells. Circulation 2003;108:1009-1014. 